\title{
Configuration Optimization Research on Tridimensional Injection-production Well Patterns of Buried Hill Reservoirs
}

\author{
Yue Yixing \\ Chongqing University of Science and Technology \\ Chongqing, China \\ yyxhenry@sina.com \\ Pang Jin \\ Chongqing University of Science and Technology \\ Chongqing, China \\ crab1981@126.com \\ Liu Hong \\ Chongqing University of Science and Technology \\ Chongqing, China \\ liubrett@vip.sina.com
}

\author{
Zhang Xu \\ Chongqing University of Science and Technology \\ Chongqing, China \\ zhang163xu@163.com \\ Pan Guijuan \\ Liaohe Oilfield Company, CNPC \\ Panjin, China \\ gjpan0321@sina.com
}

\begin{abstract}
Tridimensional injection-production well pattern has significant advantages on development of very thick buried hill reservoirs. But optimization is needed because the space configuration relation of buried hill reservoirs is very complicated. Reservoir numerical simulation techniques are applied in this study to research a buried hill reservoir. Injection-production well groups of vertical-horizontal wells and horizontal-horizontal wells are optimized respectively and comparative analyzed, based on the reliable reservoir numerical simulation model and considering about well types, well spatial positions and distance between the wells. The result shows that in tridimensional injection-production well patterns of vertical-horizontal wells, vertical injection well at bottom with an upper horizontal production well and vertical well at an angle of $\mathbf{4 5}$ degrees to end of horizontal well is the best configuration. And in that of horizontalhorizontal wells, the horizontal plane at an angle of 60 degrees to the plane that two horizontal wells in (an upper production well with a lower production well) is the best configuration, and this is more effective than that of verticalhorizontal wells. This study can provide support for the design of tridimensional injection-production well patterns of buried hill reservoirs.
\end{abstract}

Keywords- buried hill reservoir; horizontal well ; well pattern optimization; tridimensional development

\section{INTRODUCTION}

Fractured buried hill reservoirs have characteristics of fractures developing, high permeability, large thickness and good connectivity[1]. Simultaneous injection of vertical-horizontal wells is considered to be a reasonable method to develop buried hill reservoir[2]. This is very effective to put off the breakthrough and increase sweep efficiency of injection water, and it can significantly improve the effect of developing oilfield[3,4]. This developing mode of oilfield is widely applied in buried hill reservoirs all over the world[5,6]. It obviously different from general reservoir that injection-production connection of tridimensional well patterns of buried hill reservoir is much more complicated. Not only well types, well patterns and distance between the wells should be considered, but also vertical configuration of thick reservoir[7]. Therefore, optimizations of the space configuration relations of vertical-horizontal wells and horizontal-horizontal wells have been developed respectively in this study.

\section{BUILDING THE RESERVOIR MODEL}

Taking a buried hill reservoir in Bohai Bay as the prototype, injection-production configuration is optimized. The Black Oil Model of double porosity and double permeability and orthogonal grids are used in modeling. $\mathrm{X}$ axis is set from west to east of 20 cells with step length 40 meters. $\mathrm{Y}$ axis is set perpendicular to $\mathrm{X}$, from north to south of 20 cells with step length 30 meters. Cell step length of $\mathrm{Z}$ axis is the reservoir thickness that calculated from corresponding layer. Every well is located at the center of cell. This model is with 2400 nodes.

Constraints is set in every research plan according to practical production as follow:

(1) Constant liquid production in simulation are set into $50 \mathrm{~m} 3 / \mathrm{d}$ in horizontal well and $20 \mathrm{~m} 3 / \mathrm{d}$ in vertical well.

(2) Injection is equal to production in simulation.

(3) Shut in when water content became higher than $98 \%$.

(4) The result of ten-year prediction is regarded as basis in comparative study. 


\section{CONFIGURATION OPTIMIZATION OF VERTICAL-HORIZONTAL WELLS}

There are two systems in operation of injectionproduction by vertical-horizontal wells[8,9]. One is vertical injection well with horizontal production well and the other is horizontal injection well with vertical production well[10]. There are four configurations in each system, horizontal and vertical wells standing on one line in the same layer, horizontal well being inclined to vertical well in the same layer, vertical well at bottom with an inclined upper horizontal well and vertical well at bottom with an inclined upper horizontal well. The distance between horizontal well and vertical well is constant 300 meters. Other configuration parameters of simulation are shown in TABLE I.

TABLE 1. CONFIGURATION PARAMETER AND RESULT OF SIMULATION OF VERTICAL-HORIZONTAL WELL

\begin{tabular}{|c|c|c|c|c|c|c|}
\hline \multirow[b]{2}{*}{ PLAN } & \multirow[b]{2}{*}{ TYPE } & \multirow[b]{2}{*}{ CONFIGURATION } & \multirow{2}{*}{$\begin{array}{c}\text { CUMULATIVE } \\
\text { PRODUCTION, } \\
10^{4} \mathrm{t}\end{array}$} & \multicolumn{3}{|c|}{ PREDICTION } \\
\hline & & & & $\begin{array}{l}\text { production rate, } \\
t / d\end{array}$ & $\begin{array}{l}\text { water content, } \\
\%\end{array}$ & $\begin{array}{c}\text { Formation pressure, } \\
\mathrm{MPa}\end{array}$ \\
\hline A & \multirow{4}{*}{$\begin{array}{c}\text { vertical } \\
\text { injection } \\
\text { well with } \\
\text { horizontal } \\
\text { production } \\
\text { well }\end{array}$} & standing on a horizontal line in the same layer & 5.40 & 8.3 & 83.5 & 16.04 \\
\hline B & & $\begin{array}{l}\text { being inclined in the same layer (vertical well is at } \\
\text { an angle of } 45^{\circ} \text { to end of horizontal well) }\end{array}$ & 5.64 & 8.6 & 82.9 & 16.02 \\
\hline $\mathrm{C}$ & & vertical well at bottom with an upper horizontal well & 6.64 & 9.5 & 81.0 & 15.51 \\
\hline $\mathrm{D}$ & & $\begin{array}{l}\text { vertical well at bottom with an inclined upper } \\
\text { horizontal well }\end{array}$ & 7.26 & 10.1 & 79.7 & 15.25 \\
\hline$E$ & \multirow{4}{*}{$\begin{array}{c}\text { horizontal } \\
\text { injection } \\
\text { well with } \\
\text { vertical } \\
\text { production } \\
\text { well }\end{array}$} & standing on a horizontal line in the same layer & 3.16 & 5.2 & 74.1 & 16.59 \\
\hline $\mathrm{F}$ & & $\begin{array}{l}\text { being inclined in the same layer (vertical well is at } \\
\text { an angle of } 45^{\circ} \text { to end of horizontal well) }\end{array}$ & 3.25 & 5.3 & 73.6 & 16.64 \\
\hline $\mathrm{G}$ & & vertical well at bottom with an upper horizontal well & 4.62 & 8.4 & 58.0 & 16.06 \\
\hline $\mathrm{H}$ & & $\begin{array}{l}\text { vertical well at bottom with an inclined upper } \\
\text { horizontal well }\end{array}$ & 4.50 & 7.7 & 61.5 & 16.24 \\
\hline
\end{tabular}

According to the result, we can find:

(1) Type of vertical injection well with horizontal production well are much better than that of horizontal injection well with vertical production well in water drive.

(2) No matter what type the plan is, injection well at bottom with an upper production well can effectively delay water flooding.

(3) In operation of injection-production by verticalhorizontal wells, the performance of horizontal well being inclined to vertical well is better.

Based on the cognition above, further research on the best plan (Plan D) has been developed. The plane configuration that best position and distance of vertical injection well is optimized (Fig .1 and TABLE II).

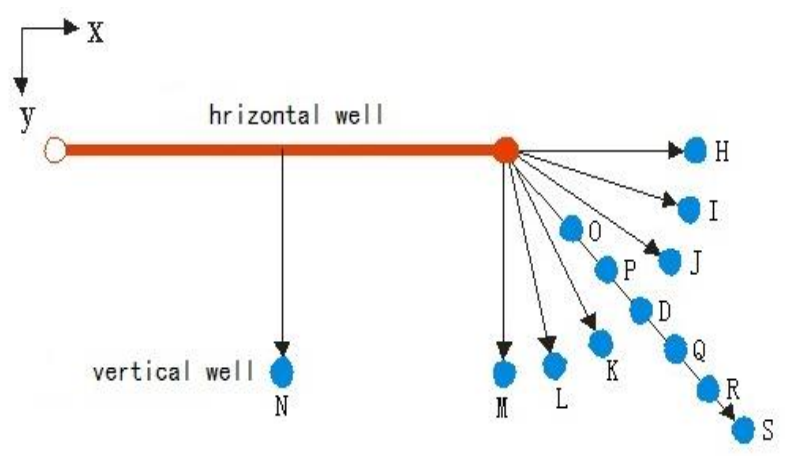

Figure 1 Position and distance of vertical injection well

TABLE II CONFIGURATION PARAMETER OF POSITION AND DISTANCE OF VERTICAL INJECTION WELL

\begin{tabular}{|c|c|c|c|c|c|c|}
\hline \multirow[b]{2}{*}{ PLAN } & \multirow{2}{*}{$\begin{array}{c}\text { POSOTIONS OF } \\
\text { VERTICAL WELL }\end{array}$} & \multirow{2}{*}{$\begin{array}{c}\text { CUMULATIVE } \\
\text { PRODUCTION, } \\
10^{4} \mathrm{t}\end{array}$} & \multicolumn{3}{|c|}{ PREDICTION } & \multirow{2}{*}{$\begin{array}{c}\text { CUMULATIVE } \\
\text { PRODUCTION } \\
\text { INCREMENT, } \mathbf{1 0}^{\mathbf{4}} \mathbf{t}\end{array}$} \\
\hline & & & $\begin{array}{c}\text { production rate, } \\
t / d\end{array}$ & $\begin{array}{c}\text { water content, } \\
\%\end{array}$ & $\begin{array}{c}\text { Formation pressure, } \\
\mathrm{MPa}\end{array}$ & \\
\hline $\mathrm{C}$ & $0^{\circ}$ to end of horizontal well & 6.64 & 9.5 & 81.0 & 15.51 & - \\
\hline I & $15^{\circ}$ to end of horizontal well & 5.64 & 8.6 & 82.9 & 16.02 & 0.23 \\
\hline $\mathrm{J}$ & $30^{\circ}$ to end of horizontal well & 6.64 & 9.5 & 81.0 & 15.51 & 0.09 \\
\hline $\mathrm{D}$ & $45^{\circ}$ to end of horizontal well & 7.26 & 10.1 & 79.7 & 15.25 & 0.30 \\
\hline $\mathrm{K}$ & $60^{\circ}$ to end of horizontal well & 3.16 & 5.2 & 74.1 & 16.59 & -0.12 \\
\hline $\mathrm{L}$ & $75^{\circ}$ to end of horizontal well & 3.25 & 5.3 & 73.6 & 16.64 & -0.05 \\
\hline M & $90^{\circ}$ to end of horizontal well & 4.62 & 8.4 & 58.0 & 16.06 & -0.11 \\
\hline $\mathrm{N}$ & $90^{\circ}$ to middle of horizontal well & 4.50 & 7.7 & 61.5 & 16.24 & -0.24 \\
\hline
\end{tabular}




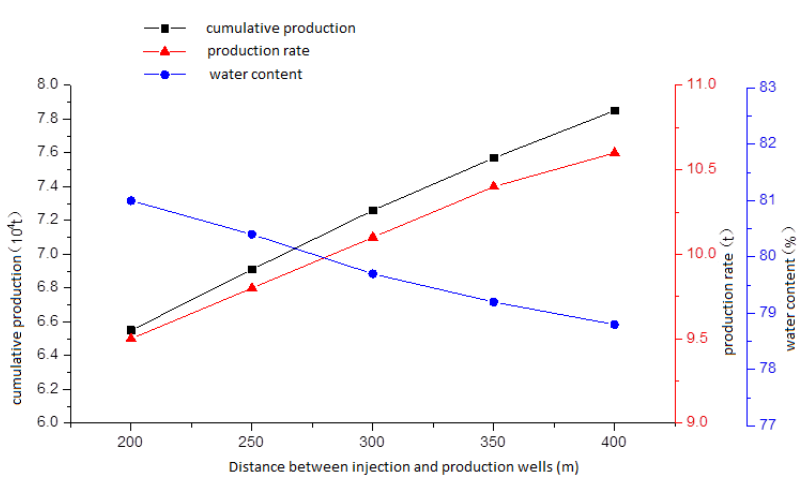

Figure 2 Prediction curves of different distance between vertical injection well and horizontal production well

We can get Main prediction parameters from numerical simulation research of vertical injection well at bottom with an upper horizontal production well, as shown in Table 2 and Fig .2. We can find that:

(1)Impact of distance on injection is a little greater than that of position.

(2) Vertical injection well at an angle of 45 degrees to end of horizontal production well is the best configuration (Plan D) with the largest swept volume, best water drive performance and highest cumulative production.

(3)Vertical and horizontal wells standing on a line has the worst water drive performance. Vertical well standing at an angle of 90 degrees to middle of horizontal well is better than standing on a line. Vertical well standing at an angle to end of inclined horizontal well is the best, and angle between 45 to 90 degrees is better than that between 0 to 45 degrees.

(4)With the distance between production and injection wells increasing, the performance of water drive become better, but cumulative production increment decreases. In this study, distance of vertical-horizontal wells in buried hill reservoir should be 300 to 400 meters.

\section{CONFIGURATION OPTIMIZATION OF HORIZONTAL-HORIZONTAL WELLS}

There are three types of configurations in operation of injection-production by horizontal-horizontal wells. They are parallel wells in a horizontal plane, vertical parallel wells and the horizontal plane at an angle to the plane that two parallel wells in. Injection wells are the lower ones in the latter two types.

The distance between wells is set into 300 meters in simulation of horizontal-horizontal wells. In simulation of parallel wells in a horizontal plane, cumulative production is 47200 tons, production rate is 7.1 tons and water content is $85.9 \%$. In that of vertical parallel wells, cumulative production is 69500 tons, production rate is 9.9 tons and water content is $80.3 \%$. And in that of the horizontal plane at an angle to the plane that two parallel wells in, cumulative production is 81200 tons, production rate is 11.8 tons and water content is $76.5 \%$. We can learn from the result of simulation that the last plan is the best and parallel wells in a horizontal plane has the worst performance in water drive.
Based on the research above, further study on optimization of angle and distance in the last plan has been developed. The angle is set into 30 degrees an 60 degrees. The distance between wells is 200 to 500 meters.

The result of simulation shows that:

(1) when angle is 30 degrees, cumulative production is 69700 tons, production rate is 9.3 tons and water content is $81.4 \%$.

(2) And when angle is 60 degrees, cumulative production is 81200 tons, production rate is 11.8 tons and water content is $76.5 \%$.

(3) We can know that the horizontal plane at an angle of 60 degrees to the plane that two parallel wells in is the better configuration. And in this configuration, with the distance between production and injection wells increasing, the cumulative production increases, but cumulative production increment decreases and formation pressure decreases obviously (Fig .3).

(4) The distance between horizontal wells of buried hill reservoir should be 300 meters in this study.

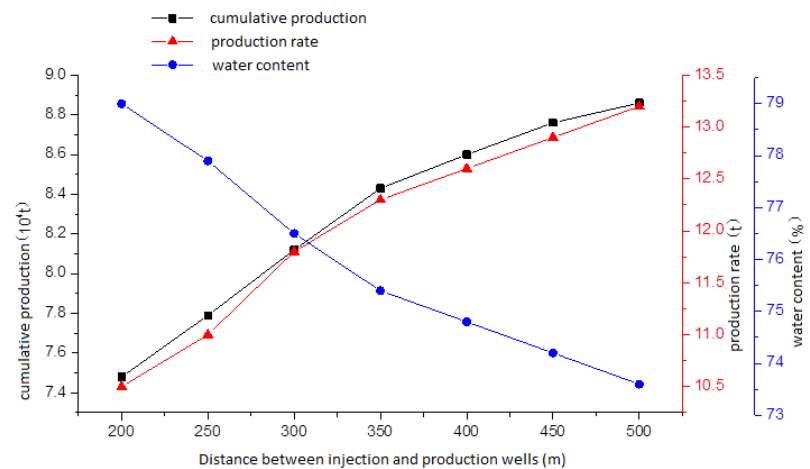

Figure 3 Prediction curves of different distance between horizontal injection and production well

\section{COMPARISON BETWEEN VERTICAL- HORIZONTAL WELLS AND HORIZONTAL- HORIZONTAL WELLS}

Configuration research of vertical-horizontal wells and horizontal-horizontal wells show that in tridimensional injection-production well patterns of vertical-horizontal wells, the plan of vertical injection well at bottom with an upper horizontal production well and vertical well at an angle of 45 degrees to end of horizontal well is the best[11,12]. And in that of horizontal-horizontal wells, the plan of the horizontal plane at an angle of 60 degrees to the plane that two horizontal wells in (an upper production well with a lower production well) is the best configuration and this is more effective than that of vertical-horizontal wells. It is $10.6 \%$ more in cumulative production, $4.66 \%$ lower in water content and $2.33 \mathrm{MPa}$ higher in formation pressure than that of vertical-horizontal wells, as shown in Fig .4. Swept area of injection well is larger and remaining oil saturation in fracture and matrix is lower in simulation of this plan. 


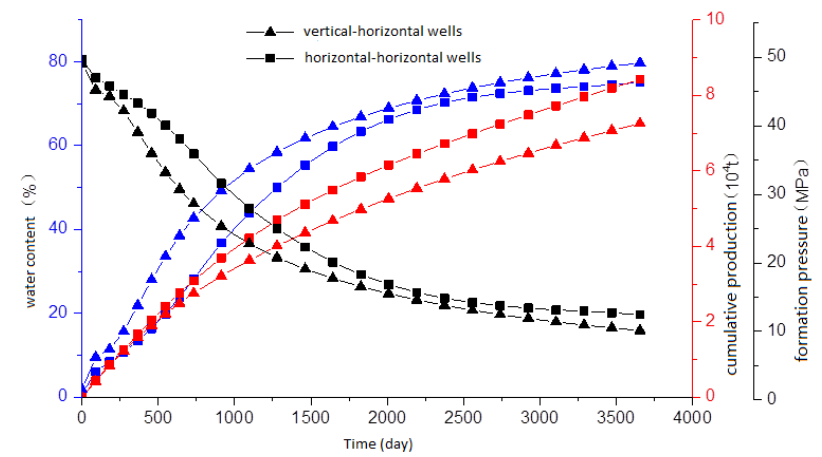

Figure 3 Comparison curves of vertical -horizontal wells and horizontal-horizontal wells

\section{CONCLUSION}

(1) In tridimensional injection-production well patterns of vertical-horizontal wells, the plan of vertical injection well at bottom with an upper horizontal production well and vertical well at an angle of 45 degrees to end of horizontal well is the best. The distance between injection and production wells in simulation is 300 to 400 meters.

(2) In that of horizontal-horizontal wells, the plan of the horizontal plane at an angle of 60 degrees to the plane that two horizontal wells in (an upper production well with a lower production well) is the best configuration. The distance between injection and production wells in simulation is about 300 meters.

(3) Configuration of horizontal-horizontal wells is more effective than that of vertical-horizontal wells. References

\section{ACKNOWLEDGMENT}

We thank the Department of Petroleum Engineering at Chongqing University of Science and Technology for providing resources and computing facilities. We gratefully acknowledge Dr. Liu Hong and Dr. Pang Jin. for their contributions during this research.

\section{REFERENCE}

[1] Xu Ning, Xu Ping, Li Man. Reasonable Development Method of Old Thick Buried Hill Reservoir[J]. Special Oil and Gas Reservoir, 2009,(03):65-67+108

[2] Zhao Chunsen, Zheng Likun, Li Wei. Research on Productivity Evaluation of Developing Fractured Buried Hill Reservoir by Horizontal Well[J]. Petroleum Geology and Engineering, 2007,(05):55-58.

[3] Jia Bingyu, "Progress and prospects of enhanced oil recovery technologies at home and abroad". Oil \& Gas Geology, 2012,01: 111-117.

[4] Qi Ligang, "The influence factor and countermeasure analysis of oilfield recovery". Chemical Engineering \& Equipment, 2014,05: 107-108. 10-23

[5] Wu Yuming, Wang Jiaying and K Qinghong."Estabilishment and application of a prediction model for enhanced oil recovery in polymer flooding".Acta Petrolei Sinica. 2013,03:513-517.

[6] Chen Kui, Experimental Design and Analysis. Beijing: Tsinghua University Press, (2009).

[7] Zeng Pingwen and L. Tiejun, Numerical Analysis. Beijing: Peking University Press, (2007).

[8] Ling Zongfa, Hu Yongle, Li Baozhu, Wang Lijuan. Well Pattern Optimization of Horizontal Injection and Production Wells[J]. Petroleum Exploration and Development, 2007,(01):65-72.

[9] Wu Yuming, Wang Jiaying and K Qinghong. "Estabilishment and application of a prediction model for enhanced oil recovery in polymer flooding”.Acta Petrolei Sinica. 2013,03:513-517

[10] Lin Yi, Wang Mingbao, Lei Ping. Application of Horizontal Well in Developing Caogu 1 Buried-hill Fractured Heavy Oil Reservoir[J]. Special Oil and Gas Reservoir,2000,(04):24-26+6364.

[11] Wang Yuming, Wang Jiaying and K Qinghong."Estabilishment and application of a prediction model for enhanced oil recovery in polymer flooding".Acta Petrolei Sinica. 2013,03:513-517

[12] C.T.Q. Dang, Z. Chen, N.T.B. Nguyen, W. Bae, and T.H. Phung. Lessons Learned and Experiences Gained in Developing the Waterflooding Concepts of a Fractured Basement-Granite Reservoir: A 20-Year Case Study[J]. Journal of Canadian Petroleum Technology,2011,50(9):75-76. 